\title{
Go online \\ - om effektiv, undervisercentreret udvikling af e-læring ved Aarhus Universitet
}

\section{Mikkel Godsk}

Specialkonsulent, cand.it, Aarhus Universitet

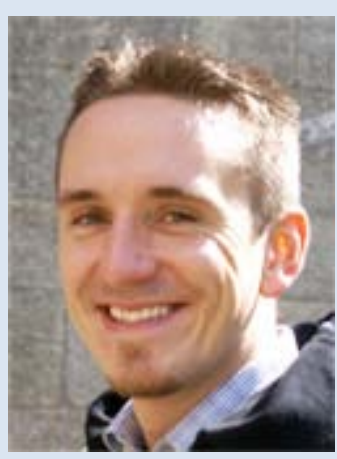

\section{Abstract}

Universiteter udvikler i stigende grad e-læring i form af webbaserede kurser. Hensigten er bl.a. at højne kvaliteten af undervisningen samt udbyde fleksible uddannelser til nye målgrupper. Det er imidlertid ikke oplagt, hvorledes udviklingen skal tilrettelægges for at være ressourcemæssig effektiv, og ofte er udbuddet af elæringsservices tilrettelagt som mindre ad hoc- og on demand-løsninger efter undervisernes ønsker. Denne tilgang er imidlertid ganske ressourcekrævende og gør det vanskeligt at imødekomme den voksende efterspørgsel på e-læring. Elæringsenheden, med støtte fra Videnskabsministeriet, lancerede derfor i 2008 projektet "go online" med det formål at udvikle og systematisere Aarhus Universitets e-læringsudbud. Den overordnede tanke med projektet var at vende udviklingen af e-læring på hovedet og således tilrettelægge e-læringsservices som en samlet og systematiseret transformeringspakke efter undervisernes behov i forhold til deres aktuelle kurser.

Artiklen præsenterer idéen med projektet, det konkrete indhold af transformeringspakken, samt erfaringerne fra pilotforløbet i 2009. Erfaringerne og evalueringen fra pilotforløbet viser, at e-læring udbudt som en samlet og systematiseret transformeringspakke kan give både gode undervisningsresultater og være ressourcemæssig effektiv - og således også gøre det muligt at udvikle e-læring i forholdsvis stor målestok med begrænsede midler. 


\section{Indledning og baggrund}

Universiteter udvikler og udbyder i stigende grad kurser, der gør brug af internettet som undervisningsmedie - ofte benævnt e-læring (Cilia et al. 2008). Ønsket er typisk at effektivisere, modernisere og højne kvaliteten af undervisningen (Paulsen 2003; Driscoll 1998; Collis \& Moonen 2001), men det er imidlertid ikke oplagt, hvorledes den egentlige udvikling skal faciliteres, og hvordan undervisningen skal tilrettelægges. Ofte tilrettelægges udviklingen af e-læringskurser og -materialer som udviklingsprojekter, hvor pædagogiske, tekniske og faglige eksperter sammen udvikler og implementerer materialerne. Sådanne udviklingsprojekter kan resultere i vellavede og nyttige e-læringsmaterialer, men ofte bliver udviklingsomkostningerne høje, og i visse tilfælde kommer materialerne til at virke isolerede og fjerne fra den reelle undervisningspraksis (Laurillard 2000; Dron 2007).

Foruden udvikling af konkrete e-læringskurser og -materialer udbyder universiteter typisk en vifte af services og tjenester - fx kurser i e-læringspædagogik, workshops i brugen af forskellige relevante teknologier, pædagogisk rådgivning, udlån af udstyr og adgang til produktionsfaciliteter, seminarer og meget andet. Kurser og seminarer er typisk afholdt efter et bestemt mønster eller på bestilling ('on demand'), og pædagogisk rådgivning varetages $\mathrm{fx}$ telefonisk eller per e-mail efter undervisernes presserende behov (Heilesen et al. 2007). Disse services må anses som vigtige og uundværlige i forbindelse med e-læringsunderstøttelse ved et universitet (jf. Ubachs 2009), men rationalet for udbuddet er ikke altid åbenlyst og begrundet i undervisernes reelle behov. Spørgsmålet er således, om indsatsen kunne optimeres ved at etablere samlede udviklingspakker, hvori disse services indgår systematiseret og er organiseret efter underviserens behov, udfordringer og aktuel undervisningspraksis frem for efter forventet efterspørgsel.

I denne artikel præsenteres idéen og erfaringerne med E-læringsenheden ved Aarhus Universitets go online-projekt (også skrevet "g8nline"1), som havde til formål at adressere de ovenstående udfordringer ved at etablere et fast og samlet transformeringstilbud af traditionel undervisning til webbaseret undervisning. De tre helt grundlæggende idéer bag projektet var:

1. Undervisningscentrering:

At brugen af e-læringsservices og udviklingen af materialer tager udgangspunkt i et konkret kursusforløb og underviserens eventuelle erfaring med formidlingen af dets pensum. Man kan populært sige, at der sættes strøm til undervisningen - den transformeres.

\footnotetext{
${ }^{1}$ Ottetallet er en sammenskrivning af de to o'er i "go online" og refererer endvidere til hensigten om at transformere 8 kursusforløb.
} 
2. Undervisercentrering:

At adgangen til e-læringsservices, herunder rådgivning og udviklingsassistance, tager udgangspunkt i underviserens faglige ekspertise samt teknologiske og e-læringspædagogiske behov.

3. En samlet pakke:

En sammentænkning af nødvendige, relevante og ofte allerede eksisterende e-læringsservices til en samlet transformeringspakke målrettet undervisere, deres kurser samt aktuelle ønsker og behov. Transformeringspakken kan udbydes til flere undervisere samtidig, samt gentages efter et fast mønster og således effektivisere e-læringsserviceudbuddet og understøtte vidensdeling underviserne imellem.

Baggrunden for projektet var et identificeret, voksende behov og efterspørgsel for e-læringsservices blandt undervisere og en samtidig konstatering af, at undervisere ikke kendte deres præcise pædagogiske og teknologiske behov for at kunne udvikle deres undervisning2. Ydermere var det umuligt at imødekomme og koordinere alle behov med de daværende ressourcer uden en videre systematisering og effektivisering. Endeligt var erfaringen, at udbyttet af en motiveret e-læringsassistance målrettet underviseren - her forstået som rådgivning og anden assistance relateret til underviserens aktuelle undervisning og e-læringsudfordringer, hvor underviseren selv deltog i udviklingen - ofte havde en stor effekt (jf. bl.a. Dalsgaard \& Godsk 2007; Godsk 2006).

Så da Ministeriet for Videnskab, Teknologi og Udvikling i 2007 lancerede en national strategi for ikt-støttet læring og dertilhørende puljemidler (Videnskabsministeriet, 2007), var det en kærkommen lejlighed til at søge om at få systematiseret og udbygget E-læringsenhedens services og aktiviteter til en samlet transformeringspakke. I forlængelse heraf fik enheden i 2008 støtte til pilotprojektet go online med opstart samme år og afslutning sommeren 2010, samt med henblik på etablering af en fast transformeringsservice.

\section{Fra 'on demand' til pakkeløsning}

E-læring er håndteret og organiseret forskelligt ved de danske universiteter, men der synes dog at være en rimelig konsensus om, hvilke grundlæggende e-læringsservices et universitet bør have. Alle danske universiteter har eksempelvis adgang til en e-læringsplatform, afholder kurser i ikt og e-læring for undervisere, pædagogisk rådgivning samt adgang til elæringsproduktionsfaciliteter eller et ikt-værksted (Heilesen et al. 2007). Tilsvarende serviceudbud eksisterede hos E-læringsenheden ved Aarhus Universitet og, som ved de fleste andre universiteter, har anvendelsen af

\footnotetext{
${ }^{2}$ Det voksende behov er bl.a. identificeret ved en vækst i antallet af henvendelser til Elæringsenheden samt antallet af kursusdeltagere i e-læringskurser i perioden 2004-2010.
} 
disse services ofte haft karakter af 'on demand', dvs. kurser afholdes, rådgivning gives og e-læringsmaterialer udvikles, når underviserne interesserer sig og oplever et behov herfor. Problemet var imidlertid, at undervisere ikke nødvendigvis vidste, hvad de præcis havde behov for af kurser, pædagogisk efteruddannelse, læringsteknologier m.m. for at kunne udvikle deres undervisning i mere webbaseret retning. I stedet syntes der at være et behov for, at underviseren blev 'taget i hånden' ved at blive tilbudt et samlet transformeringstilbud, der indeholdte dét, som var grundlæggende og nødvendigt for at kunne undervise på nettet.

Og det er her go online-idéen kom ind i billedet. I stedet for at lade undervisere deltage i og benytte sig af vilkårlige e-læringstjenester, satte go online underviserens aktuelle undervisning i fokus. Det var underviserens aktuelle kursus, der skulle transformeres, og det var således også de pædagogiske og tekniske udfordringer, dette kursus satte, som skulle adresseres vha. e-læringsservices og -assistancer. Projektet vendte så at sige den typiske håndtering af e-læring på hovedet: i stedet for at tænke i serviceudbud tilrettelagt efter undervisernes ønsker, blev e-læring tilrettelagt med henblik på at lede underviserne igennem de services, de havde behov for.

Foruden at e-læringsservices i go online blev tilrettelagt efter de aktuelle behov, så blev disse services også samlet i en bestemt kronologi tilpasset det typiske semestermønster på universitetet. Dette gjorde det muligt at detailplanlægge de forskellige elementer i transformeringen; herunder den pædagogiske efteruddannelse af underviserne, udviklingen af e-læringsmaterialerne, procedure for tildeling af projektmidler osv. Endvidere var det muligt at understøtte en vis overlevering af erfaringer og viden fra det ene hold undervisere til et eventuelt næste via eksempelvis en konference og best practice-dokumentation.

\section{Sammensætning af transformeringspakken}

Udgangspunktet for udviklingen af kurserne var primært den eksisterende undervisningspraksis og eksisterende materialer, der blev transformeret til e-læring. Indholdet af transformeringspakken var således formet efter undervisernes behov for at kunne varetage deres undervisning online og sammensat med udgangspunkt i E-læringsenhedens eksisterende elæringsservices.

At undervise online forudsætter imidlertid mere end blot en transformering af undervisningsmaterialerne. Også den pædagogiske tilgang bør tilpasses og udvikles for at sikre en god undervisning med aktiverede studerende, god brug af de udviklede e-læringsmaterialer og et højt læringsudbytte - og hvor underviserne samtidig bevarer kontrollen med formidlingen af pensum. Der findes kun få konkrete og generiske modeller til udvikling og tilrettelæggelse af webbaserede kurser. Blandt de mest 
kendte og anvendte modeller er Gilly Salmons e-tivities (Salmon 2002; 2003), Diana Laurillards designmetodologi (Laurillard 2002), Robin Masons skabelon for online kurser (Mason 1998) og adskillige skræddersyede modeller (jf. eksempelvis Bonk \& Graham 2006). Desværre er mange af de skræddersyede modeller vanskelige umiddelbart at overføre til andre læringskontekster og fagområder, ligesom flere modeller kun adresserer enkeltdele af udviklingen - eksempelvis kun de pædagogiske eller tekniske aspekter - eller kun er baseret på isolerede udviklingsprojekter. E-læringsenheden valgte derfor at tage udgangspunkt i egne førstehåndserfaringer fra vellykket tilrettelæggelse af kurser i e-læringspædagogik inspireret af Salmons e-tivities. Tanken var, inspireret af teorien om learning by doing (Dewey 1916, 1997) og mesterlære (Lave \& Wenger 1991), at underviserne lærer bedst ved selv at prøve at være studerende i en tilsvarende, social internetkontekst, som de selv skal undervise i senere. Salmons model adresserer imidlertid primært de pædagogiske aspekter, og E-læringsenheden valgte derfor at supplere kurset med introduktioner til relevante e-læringsteknologier.

Foruden det e-læringspædagogiske kursus var transformeringspakken sammensat af en række andre services og aktiviteter. Den samlede pakke blev derfor sammensat af følgende services:

- En procedure for håndtering af ansøgning og tildeling af projektmidler

- Et webbaseret kursus for undervisere i at undervise på nettet

- Løbende pædagogisk og teknisk rådgivning i e-læring

- Facilitering af løbende erfaringsudveksling imellem underviserne

- Assistance til udvikling af e-læringsmaterialer

- Best practice-opsamling og -formidling

- E-læringskonference for hele universitetet samt eksterne interessenter

- Kåring af årets 'e-underviser' ved universitetet.

Dertil kom et par mindre delaktiviteter omhandlende rådgivning i ophavsret og hjælp til clearing af undervisningsmaterialer, som dog ikke viste sig aktuelle i det første go online-forløb.

\section{Håndtering af e-læringsprojektmidler}

Universiteter har typisk afsat midler til e-læringsudviklingsprojekter, og med et relevant projekt og en passende medfinansiering kan en underviser eller et institut ansøge om nødvendige udviklingsmidler. Go online byggede på en tilsvarende idé; at en underviser kunne ansøge om udviklingsassistance, men i stedet for at underviseren skulle bruge tid på at detailbeskrive sit udviklingsprojekt eller indhente tilbud, definerede go online rammerne for assistancen, herunder deadlines, indhold, afrapporteringsform m.m. Tilsvarende forenkledes administrationen af projektmidlerne 
da såvel behandling af ansøgninger, tildeling af midler, håndtering af udbetaling som evaluering lå inden for faste rammer med én (årlig) deadline. Projektmidlerne bestod i adgang til de ovenstående services, herunder den nødvendige assistance i forhold til bemanding og teknologi, og krævede således kun medfinansiering fra underviserens og instituttets side i form af allokering af tid. Betingelsen for at deltage i projektet var, foruden et krav om at ansøge og blive optaget, at underviseren havde opbakning fra eget institut om deltagelse i projektet og deltog i de nødvendige aktiviteter, herunder også best practice-opsamling og andre vidensdelingsakvititeter.

Annonceringen af projektet og ansøgningsfristen lå om efteråret, således at nye deltagere kunne optages med opstart det efterfølgende forår. Ansøgerne blev bedt om at benytte et ansøgningsskema, der bl.a. spurgte til kursus, institut, kursets målgruppe, pædagogiske udfordringer, idéer til udvikling samt motivation for at deltage i projektet. Den egentlige udvælgelse blev foretaget af e-læringskonsulenterne og projektets leder ved E-læringsenheden på baggrund af en række foruddefinerede kriterier vedr. bl.a. faglig og e-læringsmæssig diversitet samt grad af innovation. Ved den første runde af go online blev der tilstræbt en maksimal diversitet i forhold til faglighed, pædagogiske udfordringer, nødvendig teknologi, undervisningspraksis, undervisningsform, studentersegment og transformeringsgrad (delvis webbaseret versus helt online). Ønsket om diversitet var begrundet i projektets formål om at etablere et fast transformeringstilbud ved universitetet, og derfor at afprøve og indhente erfaringer inden for flest mulige forskelligartede e-læringssituationer.

\section{Kursus i at undervise på nettet samt facilitering af erfaringsudveksling}

At undervise via nettet kræver særlige pædagogiske kompetencer og teknisk viden. Go online-forløbet inkluderede derfor et 4 ugers webbaseret kursus i e-læringspædagogik inspireret af Gilly Salmons model for e-tivities (Salmon 2002, 2003). Foruden at introducere til undervisningsformen og den særlige e-pædagogik ved bl.a. at lade underviserne selv være studerende via nettet, introducerede kurset også til relevante teknologier og understøttede online socialisering samt erfaringsudveksling imellem underviserne. Kurset blev opstartet ved et indledende face-to-face-møde, hvor rammerne for projektet, 'den teknologiske værktøjskasse' (se tabel 2) samt læringsrummet blev præsenteret, og et e-læringskit bestående af headset og webkamera udlåntes. Efter face-to-face-mødet foregik undervisningen online og var struktureret i 4 moduler (også benævnt "trin") af en uges varighed (se tabel 1).

Hvert modul bestod af en række lektioner/e-tivities afspejlet i modulets indholdsbeskrivelse (se eksempel på e-tivity i figur 1). 


\begin{tabular}{|c|c|}
\hline Moduler & Indhold \\
\hline $\begin{array}{l}\text { Introduktion: } \\
\text { 23. feb. - 1. marts } 2009 \\
\text { Adgang og motivation (trin 1) }\end{array}$ & $\begin{array}{l}\text { Introduktion } \\
\text { Velkomst } \\
\text { Formål } \\
\text { Kursusmodel } \\
\text { E-tivities og tidsforbrug } \\
\text { Kursusplan } \\
\text { Roller }\end{array}$ \\
\hline $\begin{array}{l}\text { Modul 1: } \\
\text { 2. - 8. marts } 2009 \\
\text { Online socialisering (trin 2) }\end{array}$ & $\begin{array}{l}\text { Online kommunikation } \\
\text { Erfaringer med ikt } \\
\text { Udfordringer i din undervisning } \\
\text { Styrk dine kompetencer } \\
\text { Refleksion }\end{array}$ \\
\hline $\begin{array}{l}\text { Modul 2: } \\
\text { 9. - 15. marts } 2009 \\
\text { Informationsudveksling og } \\
\text { vidensopbygning, herunder } \\
\text { afprøvning af teknologier (trin 3 - 4) }\end{array}$ & $\begin{array}{l}\text { Brug af wiki } \\
\text { Brug af videokonference } \\
\text { Brug af podcasts } \\
\text { Brug af læringsobjekter } \\
\text { Refleksion }\end{array}$ \\
\hline $\begin{array}{l}\text { Modul 3: } \\
\text { 16. - 22. marts } 2009 \\
\text { Videnskonstruktion, herunder } \\
\text { udvikling af egen plan (trin } 4 \text { - 5) }\end{array}$ & $\begin{array}{l}\text { Udvikling af fælles idékatalog } \\
\text { Udvikling af transformeringsplan } \\
\text { Refleksion }\end{array}$ \\
\hline
\end{tabular}

Tabel 1: Oversigt over det e-læringspædagogiske kursus.

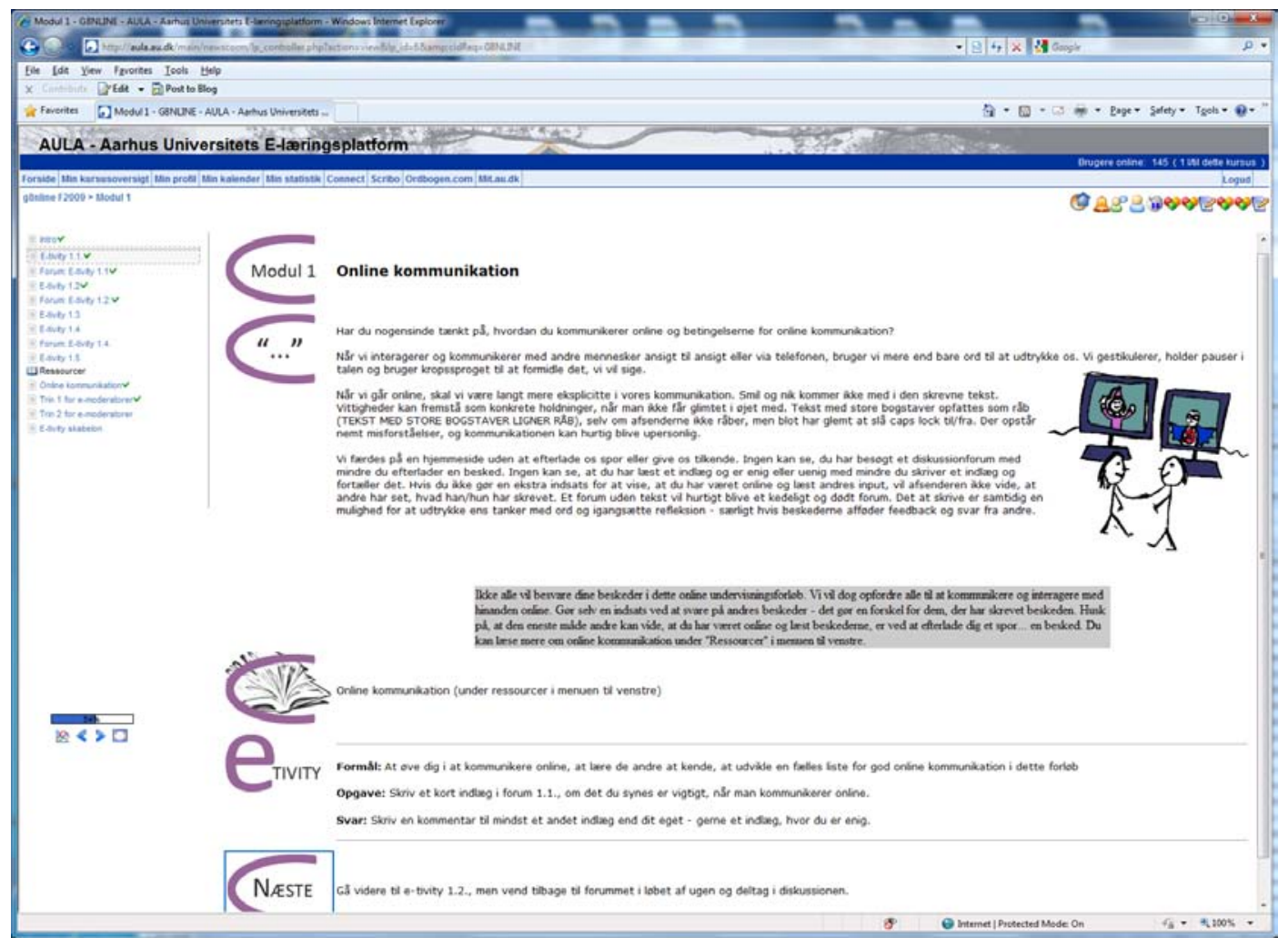

Figur 1. Eksempel på e-tivity fra Modul 1 implementeret i AULA. 
Efterfølgende erfaringsudvekslingsmøder blev arrangeret efter undervisernes ønsker og behov, hvortil E-læringsenheden stillede lokaler til rådighed og sørgede for indkaldelse, forplejning og opfølgning.

Kurset blev skemalagt til det tidlige forår, således deltagerne havde tid til at forberede deres undervisning og udvikle e-læringsmaterialer til brug ved efterårets undervisning.

\section{Pædagogisk og teknisk rådgivning samt udviklingsassistance}

Efter endt kursus i e-læringspædagogik begyndte underviserne at planlægge deres undervisning. Der var som udgangspunkt afsat tid til to konsulentmøder, hvor hhv. de overordnede ønsker til transformering blev afstemt og udviklingen af e-læringsmaterialer blev planlagt. Afhængigt af det enkelte kursus, herunder graden af transformering og de påkrævede teknologier, var behovet for pædagogisk og teknisk rådgivning og udviklingsassistance meget forskelligt. Endvidere var det i nogle tilfælde muligt at forberede undervisningen og e-læringsmaterialerne i god tid, mens det i andre tilfælde først var muligt at producere materialerne i løbet af undervisningssemestret - eksempelvis ved podcasting af forelæsninger.

Udgangspunktet var, at underviseren selv stod for tilrettelæggelsen af undervisningen og benyttede sig af de teknologier, som go online stillede til rådighed (jf. 'værktøjskassen', tabel 2). I enkelte tilfælde ville underviseren selv stå for tilrettelæggelsen af næsten al undervisningen på baggrund af det e-læringspædagogiske kursus og de indledende konsulentmøder, men i de fleste tilfælde havde underviseren behov for løbende pædagogisk og teknisk rådgivning samt assistance til udvikling af e-læringsmaterialerne og lån af udstyr. De deltagende undervisere fik alle tilknyttet en e-læringskonsulent fra E-læringsenheden, der kunne konsulteres efter behov både i forberedelses- og i undervisningsperioden. E-læringskonsulenten var sammen med underviseren og projektets øvrige projektgruppe - projektets leder, programmør og podcastproducer m.fl. - , endvidere med til at planlægge eventuel ekstraordinær assistance. Dette kunne fx dreje sig om særlige systemudviklinger, tilpasninger af e-læringsplatformen, indkøb af supplerende it-udstyr, assistance til podcasting og udvikling af læringsobjekter. 


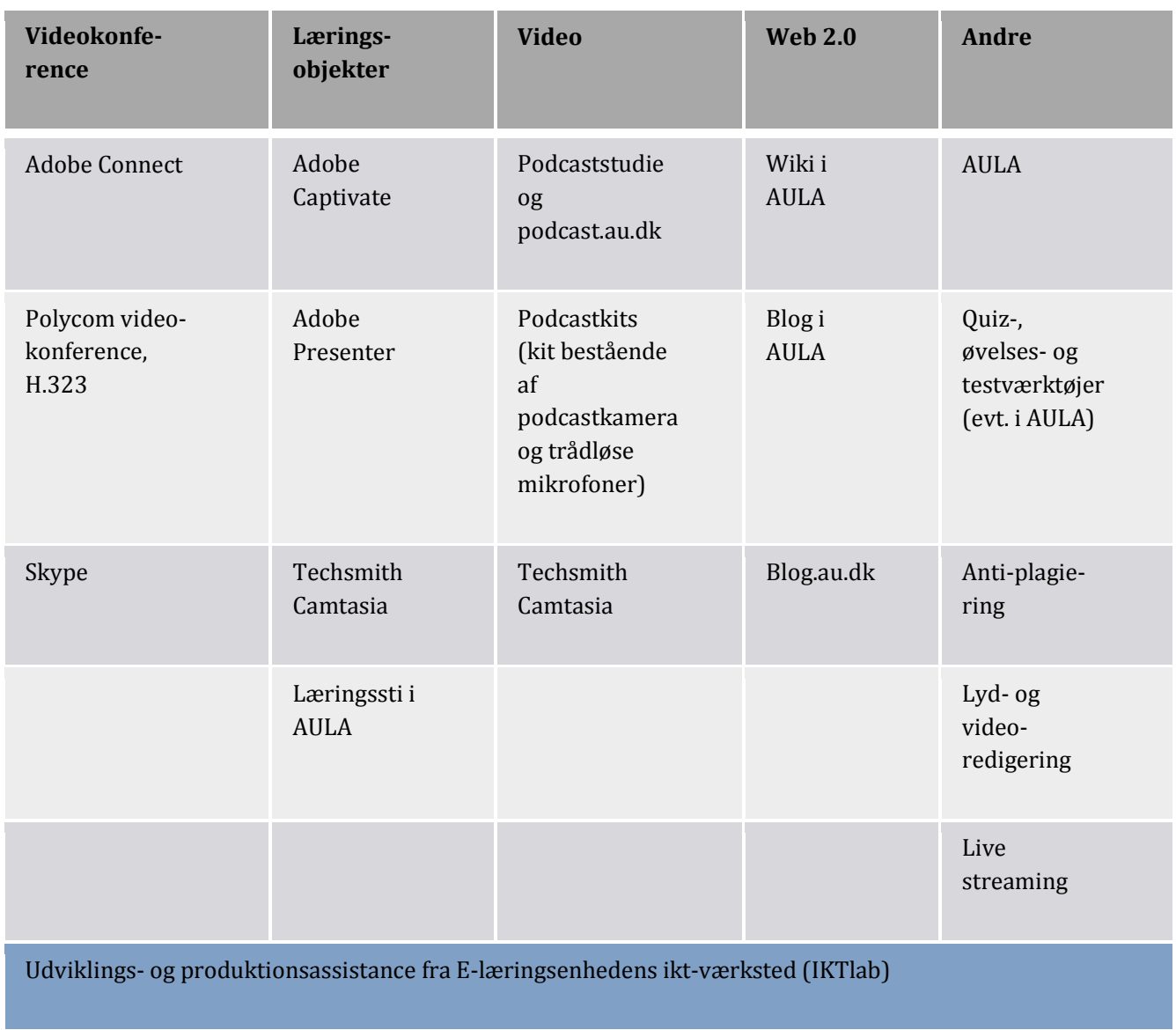

Tabel 2: Den teknologiske værktøjskasse med en oversigt over supporterede e-læringsteknologier og -systemer. Ikke alle nævnte teknologier kom i brug ved go online 2009-forløbet, ligesom enkelte andre værktøjer og ressourcer blev inddraget. AULA er universitets e-læringsplatform, der er baseret på Dokeos 1.8.4 (Dokeos, 2010).

\section{Best practice-opsamling og -formidling}

Et vigtigt aspekt af go online-projektet var eksplicitering, opsamling og formidling af den genererede viden og erfaringer. Den opsamlede viden blev brugt til at inspirere nye deltagere i go online samt andre undervisere lokalt, nationalt og internationalt (jf. bl.a. Hayes et al., 2009). Erfaringerne blev opsamlet vha. en webformular og dertil hørende database, hvori underviserne selv skrev et resumé af deres projekt, informationer om anvendte pædagogikker og teknologier, deres erfaringer m.m. efter endt undervisningssemester. Disse informationer blev efterfølgende gjort tilgængelige og søgbare på projektets hjemmeside (se figur 2). En kommende deltager i go online og andre undervisere kunne herefter på egen hånd søge efter inspiration til anvendelsen af e-læring ved at lære mere om andre underviseres anvendelse af bestemte teknologier, e-læring ved forskellige fagligheder, pædagogiske principper, de studerendes reaktioner mv. Da undervisningssemesteret sluttede omkring nytår, forelå beskrivelserne fra de netop transformerede kurser tilgængeligt. 


\section{E-læringskonference og kåring af årets e-under- viser}

Som en supplerende aktivitet til vidensdeling omkring e-læringsfeltet, dets muligheder og promovering af go online, blev projektet afsluttet med en elæringskonference. Til konferencen blev projektets deltagere, undervisere ved universitetet, beslutningstagere, forskere i feltet og andre interne og eksterne interessenter inviteret. Konferencen var ikke snævert fokuseret på go online-projektet, men behandlede flere forskellige relevante aspekter af facilitering og anvendelse af e-læring ved et universitet, herunder strategiske betragtninger samt gode erfaringer om organisering og anvendelse $\mathrm{i}$ undervisningspraksis. På programmet var der oplæg ved udvalgte undervisere, der havde transformeret deres undervisning via go online samt

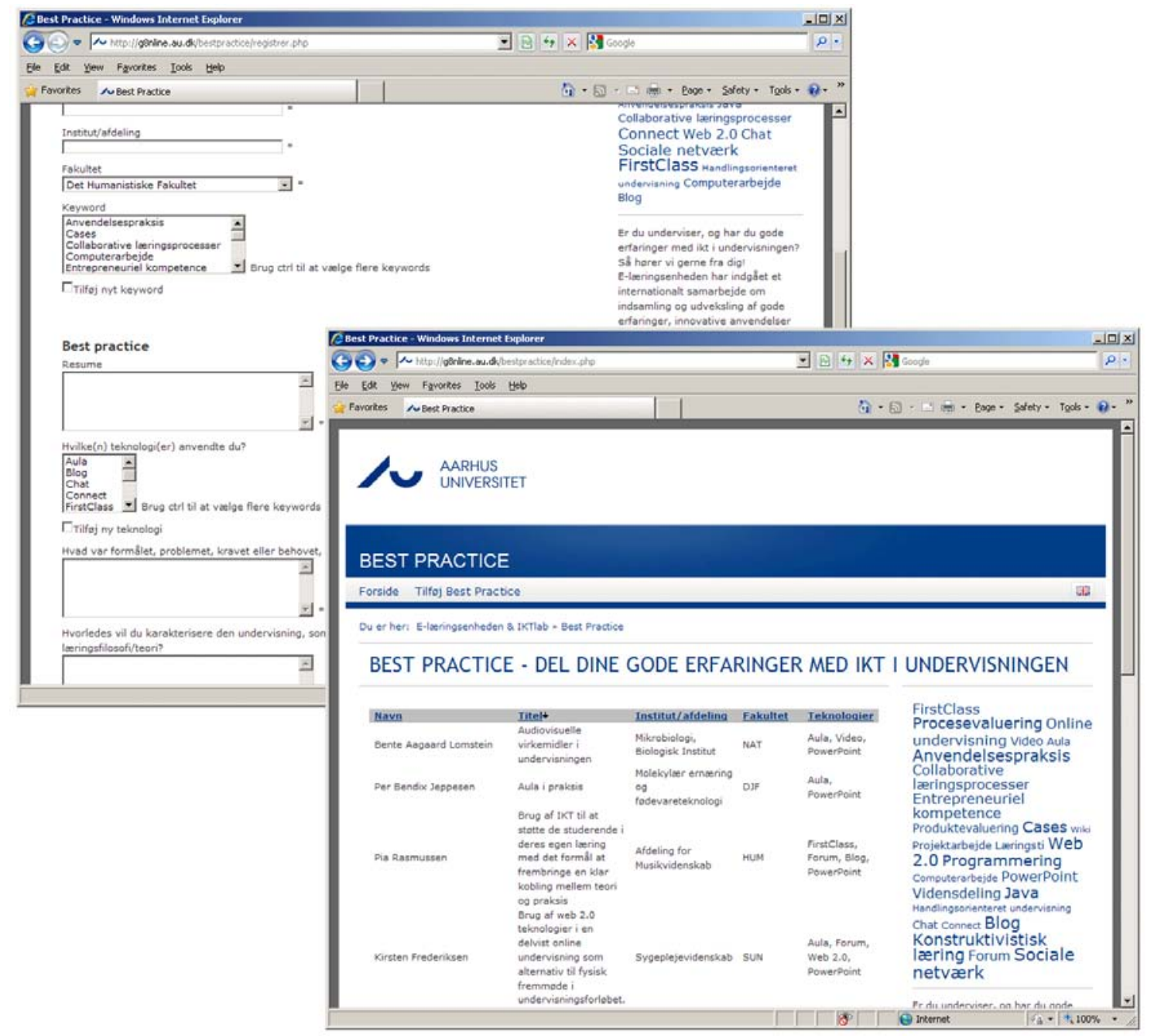

Figur 2. System til indtastning og deling af best practice. Underviserne kunne selv indtaste deres erfaringer, og det var muligt for alle at søge på best practice vha. tags, anvendte teknologier, afdeling og kursus. Foruden den søgbare database blev der ved afslutningen af go online 2009 designet et webmagasin til supplerende promovering af projektet og inspiration for andre undervisere ved universitetet. 
præsentationer ved forskellige eksperter inden for e-læringsfeltet. Ydermere blev årets e-underviser ved Aarhus Universitet kåret og prisen overrakt af projektets protektor, som i 2009 var prorektor. Vinderen blev kåret blandt deltagerne i go online af en jury bestående af en forsker i e-læring, lederen af universitetets pædagogiske netværk (Universitetspædagogisk Netværk) samt repræsentanter fra E-læringsenhedens projektgruppe. Kriterierne bestod bl.a. i en vurdering af læringseffekten, graden af innovation, interaktionen med de studerende, studentertilfredshed og processen. Vurderingsgrundlaget bestod i resultatet af transformeringen (dvs. elæringskurset), forløbet og processen, de studerendes evalueringer og evt. måling af deres læringsudbytte samt det beskrevne best practice-eksempel. Prisen bestod, foruden anerkendelsen, i en check på $25.000 \mathrm{kr}$.

Konferencen blev afholdt ved pilotprojektets afslutning i marts 2010, således at også nye deltagere kunne deltage og hente inspiration i de netop gennemførte transformeringer. Endvidere blev oplæggene på konferencen podcastet, så også andre undervisere og eksterne interessenter kunne have glæde af de erfaringer og den viden, der blev præsenteret. Konferencen i 2010 havde godt 115 tilmeldinger.

\section{Processen i go online}

Elementerne i transformeringspakken var planlagt således, at processen kunne gentages årligt, og nye deltagere kunne bygge videre på viden og erfaringer fra det tidligere forløb via bl.a. den årlige konference og best practice-databasen. Processen er illustreret i figur 3.

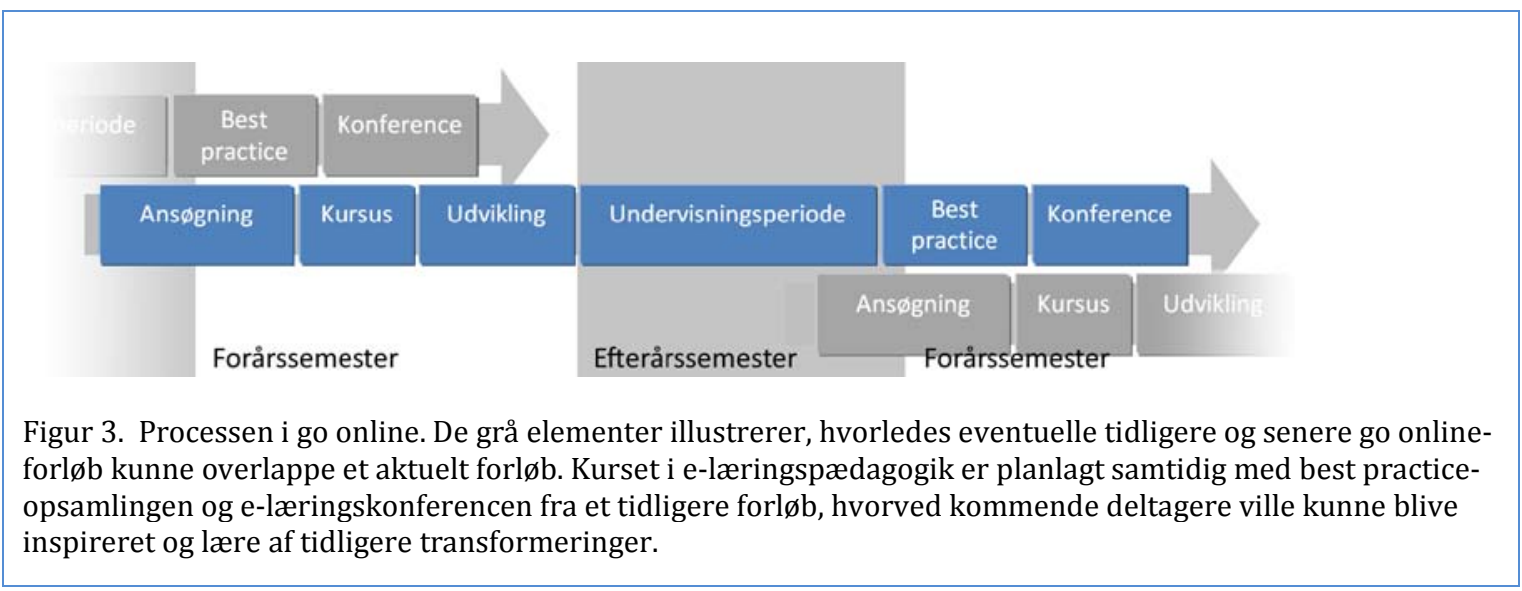

\section{Kurser i go online 2009}

E-læringsenheden fik i 2008 støtte til første runde af go online med opstart i efteråret samme år. Muligheden for deltagelse i projektet blev annonceret til universitets undervisere i efteråret 2009. 18 undervisere, nogen med mere end ét kursus, ansøgte om deltagelse og 9 blev optaget, hvoraf 7 gen- 
nemførte hele projektforløbet (succeskriteriet var minimum 6). Som tidligere beskrevet var der en række foruddefinerede kriterier vedr. diversitet, som dannede grundlag for udvælgelsen. Dette resulterede i 7 meget forskellige transformerede kurser:

- User driven innovation management ved lektor Kristina Risom Jespersen, Institut for økonomi.

Formålet var at skabe en større overensstemmelse mellem kursets indhold (innovation) og dets form, at skabe et højere lærings- og refleksionsniveau vha. it-værktøjer samt formidle teori, opgaveløsning og samarbejde via nettet.

Anvendte teknologier: AULA, wiki til opbygning af vidensbank, diskussionsfora, teoriintroducerende podcasts optaget i podcaststudiet, weblogs til refleksion, samt eksterne fagspecifikke webressourcer.

- Entrepreneurship i oplevelsesøkonomien ved studielektor Pia Rasmussen, Institut for Estetiske fag, Afdeling for Musikvidenskab. Formålet var at skabe et lærende fællesskab, at understøtte gruppearbejde og diskussioner, at etablere et tværfagligt forum samt fokusere på idéudvikling og proces.

Anvendte teknologier: wiki, diskussionsfora, AULAs gruppeværktøj til samarbejde og idéudvikling samt læringssti og Adobe Captivate til vejledning og introduktion.

- Journalistisk tekstproduktion ved ekstern lektor Kirsten Sparre, Institut for Sprog og Erhvervskommunikation. Formålet var at give de studerende mulighed for at forberede sig, gennemgå og repetere teori via nettet samt at frigøre undervisningstid til flere praktiske øvelser. Anvendte teknologier: Læringsstier, diskussionsfora, weblogs og læringsobjekter udviklet i Adobe Captivate.

- Historisk metode ved lektor Claus Møller Jørgensen, Institut for historie og områdestudier.

Formålet var at undervise i historisk metode via nettet, at variere undervisningen samt udvikle genanvendelige undervisningsmaterialer.

Anvendte teknologier: Læringsstier, weblogs, podcasts optaget $i$ podcaststudiet samt læringsobjekter udviklet i Adobe Captivate.

- Odontologisk biokemi ved studielektor Søren Læssøe Mathiesen, Institut for Medicinsk Biokemi.

Formålet var at motivere de studerende til at skabe en fælles forståelse af kursets indhold via diskussioner på nettet. Anvendte teknologier: Diskussionsfora og læringsstier.

- Metoder til forskning i sygepleje ved post doc Kirsten Frederiksen, Institut for Folkesundhed, Afdeling for Sygeplejevidenskab.

Formålet var at udvikle et fjernundervisningstilbud som et parallelt tilbud til den traditionelle tilstedeværelsesundervisning. Anvendte teknologier: diskussionsfora, chat, videokonference via Adobe Connect, korte introducerende videoklip og læringsstier. 
- Strategisk Ledelse og Organisation ved adjunkt Anders McIlquhamSchmidt, Institut for Ledelse.

Formålet var at give mulighed for repetition af undervisningen samt variere formen ved at inddrage digitale medier.

Anvendt teknologi: Podcasts af forelæsningerne.

Tre af disse kurser var på bachelorniveau, mens fire var på kandidatniveau. Samlet set har omkring 560 studerende fulgt ét eller flere af disse kurser. Med undtagelse af kurset "Metoder til forskning i sygepleje" er alle kurserne tænkt som blended learning, hvor de webbaserede undervisningsmaterialer enten er en del af eller supplerer tilstedeværelsesundervisningen.

\section{Evaluering af go online 2009}

Som et led i erfaringsopsamlings-, konsoliderings- og projektarbejdet er go online løbende blevet evalueret. Der kan være adskillige hensigter med evaluering, og man skelner typisk mellem fem forskellige evalueringsformål i relation til undervisning, herunder motivering og vurdering af den studerende, selvevaluering af læringsudbytte og evaluering af et undervisningsforløbs effektivitet (Dirks 1997). I forbindelse med go online var det primært undervisningens effektivitet og kvalitet, der blev evalueret. Dette fokus skyldes dels projektets formål om at etablere en effektiv e-læringsudvikling i ressourcemæssig forstand, dels et ministerielt krav om en kvalitets-/slutevaluering for at kunne få udløst puljemidlerne. Måling af undervisningskvalitet er relateret til evnen til at opnå det ønskede læringsudbytte med den planlagte undervisning (Garrison \& Anderson 2003). Dette kan således måles direkte på eksamensresultaterne og indirekte på undervisernes og de studerendes vurdering af det faglige udbytte. Den ressourcemæssige effektivitet kan i den forbindelse måles på omkostningerne til udviklingen af undervisningen. Såvel undervisernes som de studerendes mening og udbytte blev løbende målt i go online 2009. Konkret er følgende spørgeskemaundersøgelser og evalueringer blevet gennemført:

- $\quad$ Undervisernes kompetencer teknisk og e-læringspædagogisk, erfaringer med e-læring samt brug af internetteknologier forud for det e-læringspædagogiske kursus (februar 2009)

- $\quad$ Undervisernes evaluering af det e-læringspædagogiske kursus og egen indsats. Evalueringen blevet foretaget umiddelbart efter kurset (april 2009)

- $\quad$ De studerendes erfaringer med og forventninger til e-læring og it forud for semesterstart (september 2009)

- $\quad$ De studerendes erfaringer med at være studerende på et elæringskursus. Evalueringen blev foretaget umiddelbart efter semesterafslutningen (december 2009)

- Undervisernes vurdering af deres gennemførte, transformerede kursusforløb, herunder antal studerende, oplevet frafald og fagligt 
udbytte, e-læringens indflydelse på undervisningen samt deres egne e-læringskompetencer. Evalueringen blev foretaget februarmarts 2010 .

Evalueringerne blev gennemført som webbaserede spørgeskemaer. Derudover blev der arrangeret et par korte, kvalitative evalueringsworkshops for underviserne, ligesom projektets slutafrapportering indebar en større skriftlig evaluering af såvel projektforløbet som dets udbytte.

Resultaterne af disse evalueringer gør det muligt at adressere projektets helt grundlæggende idéer: undervisningscentrering, undervisercentrering og idéen om en samlet ressourceøkonomisk pakke.

\section{Underviser- og undervisningscentrering}

Go online har fra start været tænkt som et underviser- og undervisningscentret projekt, og aktiviteterne i projektet har derfor været rettet mod at styrke underviserens e-læringskompetencer til selv at udvikle deres egen undervisningspraksis og et konkret kursus. En spørgeskemaundersøgelse ved projektets start blandt underviserne gav en række udsagn med tilsvarende argumenter for deltagelsen i projektet (i prioriteret rækkefølge):

- Mulighed for videreudvikling af undervisning

- Teknisk støtte fra E-læringsenheden

- Adgang til inspirationsmateriale

- It-pædagogisk støtte fra E-læringsenheden

- Mulighed for at styrke pædagogiske kompetencer.

Kun én af underviserne havde tidligere deltaget i projekter med fokus på undervisningsudvikling vha. e-læring, hvilket også kom til udtryk som en bekymring i forhold til teknik og tidsforbrug. Forud for projektets opstart forventede $50 \%$ af underviserne, at tiden ville blive den største udfordring, efterfulgt af en bekymring vedr. tekniske aspekter ( $20 \%$ af underviserne), samt de studerendes reaktion på webbaseret undervisning (20\% af underviserne). Undervisernes forudgående tekniske og pædagogiske kompetencer var meget forskellige, og kun én deltager vurderede at have gode forudgående it-pædagogiske kompetencer. De mest udbredte teknologier brugt i undervisningen var forud for det e-læringspædagogiske kursus: e-læringsplatformene (AULA/Dokeos, CampusNet og Blackboard), e-mails samt sider for litteratursøgning. Dog var der også enkelte undervisere, som havde anvendt web 2.0-teknologier så som fx YouTube, Flickr og Wikipedia/wikier.

Alle underviserne oplevede et godt eller meget godt udbytte af det elæringspædagogiske kursus, ligesom alle mente, at det levede op til deres forventninger. Endvidere oplevede alle underviserne, at de i nogen eller høj grad havde fået en tilfredsstillende introduktion til, hvordan rollen som e-underviser skulle varetages, samt hvordan de tekniske faciliteter skulle 
anvendes. Underviserne brugte 2-5 timer om ugen i 4 uger på det elæringspædagogiske kursus, men ville ønske at de kunne have brugt lidt mere tid.

I forhold til undervisningspraksis oplevede alle underviserne, at de $i$ høj grad havde været med at til både udvikle og forfatte e-læringsmaterialerne, tilrettelægge deres kursus og varetage den egentlige gennemførelse heraf. Med undtagelse af én, vurderede alle underviserne, at deres studerende havde fået et større fagligt udbytte ved at kurset var e-læringsbaseret (heraf $43 \%$ i høj grad), og at det havde givet særlige kompetencer til de studerende, som de ellers ikke havde opnået. Alle underviserne vurderede, at de studerende havde bedre muligheder for at lære i overensstemmelse med egne behov og forudsætninger. Ca. halvdelen af underviserne fandt det mere tidskrævende at udvikle og undervise vha. e-læring, mens den anden halvdel oplevede stort set det samme tidsforbrug.

Alle undervisere angav i deres evaluering, at de $i$ høj grad havde lyst til at være underviser på et lignende kursusforløb med e-læring igen. Endvidere betragtede alle underviserne sig som selvkørende i forhold til anvendelsen af e-læring i deres undervisning fremover, og alle, med undtagelse af én, der svarede "ved ikke", ville anbefale såvel go online som generel brug af elæring til andre undervisere. Endeligt skønnede underviserne, at 5 ud af de 7 transformerede kurser oplevede en mindre, nogen eller høj grad af forbedring af karaktergennemsnittet ( 2 svarede "ved ikke").

Undervisernes positive erfaringer med at blive selvkørende e-underviser, de opnåede pædagogiske og tekniske kompetencer samt de forbedrede eksamensresultater tyder på, at idéen om underviser-og undervisningscentreret e-læringsudvikling er realistisk og indeholder visse potentialer. De deltagende undervisere havde ingen særlige forudgående tekniske eller pædagogiske e-læringskompetencer, så succesen må i høj grad tilskrives undervisernes motivation for at udvikle deres egen, aktuelle undervisningspraksis, samt hvorledes denne er imødekommet i go online. Naturligvis har ikke alle undervisere den samme motivation for at udvikle deres undervisning vha. e-læring, og derfor er der en risiko for, at det på et tidspunkt bliver vanskeligt at finde motiverede undervisere til at fortsætte den undervisercentrede udvikling via projekter som go online. Der opleves imidlertid en generelt voksende interesse for e-læring og diverse webteknologier blandt undervisere, ligesom en god oplevelse fra projekter som go online kan sprede sig som ringe i vandet blandt universitetets øvrige undervisere. Der er derfor ingen grund til at tage bekymringerne på forskud, ligesom det gentagne gange er bevist, at man skal undlade at spå om fremtidens teknologiske situation. 


\section{En billig pakkeløsning}

Go online 2009s samlede budget var på 1,6 million kr, hvoraf store dele var opstartsomkostninger til etablering, konsolidering, udvikling af teknologier, indkøb af udstyr, ekstraordinær projektdokumentation samt løn til projektmedarbejderne. Det seneste regnskab tyder imidlertid på, at de reelle omkostninger bliver noget lavere (regnskabet er i skrivende stund, august 2010, endnu ikke opgjort). Endvidere var det planen for fremtiden at tilrettelægge parallelle go online-forløb samt opjustere deltagerantallet, og derved minimere omkostningerne yderligere.

Go online handler således langt hen ad vejen om at tilrettelægge allerede eksisterende e-læringsservices efter en bestemt kronologi og udviklingsmodel samt at tildele det medarbejderressourcer. Det er et universitets organisering af e-læring samt dets e-læringsserviceportefølje og -kompetencer, som er bestemmende for prisen på pakkeløsningen. Næsten alle danske universiteter har allerede etableret mange af de nødvendige, basale services - og har måske endda supplerende, nyttige elementer - og har således byggeklodserne til go online. I de tilfælde kan go online måske ligefrem være med til at udvide omfanget af e-læringsservices, da systematiseringen af eksisterende udbud kan forenkle planlægningen.

\section{Konklusion og anbefalinger}

E-læring kan faciliteres og udvikles på mange måder, og typisk har dette været gjort vha. et e-læringsserviceudbud, hvor undervisere, mere eller mindre frivilligt, 'shopper' i et udbud af forskellige kurser, projektmidler samt teknisk og pædagogisk konsulentassistance efter deres aktuelle $\emptyset$ nsker og behov. Denne forholdsvis fragmenterede måde at udbyde elæring på er meget fleksibel og har derfor sin berettigelse ud fra en almindelig 'on demand' servicetankegang, men hvis et universitet ønsker at udvikle mere end blot enkelte e-læringskurser og -materialer i ny og næ uden samtidig at skulle forøge budgetterne til e-læring markant, kan det være nødvendigt at systematisere udbuddet yderligere - eksempelvis vha. større services som go onlines transformeringspakke. Dette er ikke kun en $ø$ konomisk fordel i forhold til nødvendige medarbejderressourcer, men ligeledes en administrativ forenkling, da udbuddet af e-læringsservices struktureres efter en fast plan og således ikke kræver yderligere planlægning og koordinering. Endvidere vil visse nye, relevante e-læringsservices kunne passes ind i pakken og ikke skulle udbydes separat. Dertil kommer, at det er enkelt og relativt billigt at øge antallet af deltagere i et projekt som go online. Prisen på en transformering afhænger primært af de teknologiske behov samt behovet for løbende konsulentassistance, men eftersom de grundlæggende services og elementer ofte allerede er tilrettelagt, handler det 'blot' om at skalere disse til en passende størrelse og sætte dem i system. Der kan naturligvis opstå problemer, hvis deltagerantallet kommer under en kritisk masse. Dette problem er dog ikke anderledes end ved 
udbud af andre e-læringsservices, hvor der ligeledes er risiko for aflyste kurser eller for lav belægning.

Omkostningerne til igangsætning af e-læring kan være relativt høje. Som ca. halvdelen af de deltagende underviserne angiver, må det forventes, at udviklingen og forberedelsen af e-læring kommer til at kræve lidt længere tid ved første afholdelse. Hvis et kursus gentages, ville denne tid dog kunne spares, da visse materialer og erfaring om tilrettelæggelse ville kunne genbruges. Ligeledes var de økonomiske omkostninger til selve projektet relativt høje pga. etablerings- og projektomkostningerne med ca. $2.000 \mathrm{kr}$ per studerende, men med en fornuftig konsolidering i eksisterende elæringspraksis og justering af udbud burde dette tal kunne halveres. Dertil kommer, at e-læring potentielt kan generere indtægter ved at gøre det muligt at udbyde kurser og uddannelser som fjernundervisning, øge optaget, udbyde fleksibel efter- og videreuddannelse til nye målgrupper, samt potentielt sikre en højere gennemførelseskvotient i kraft af bl.a. elæringsmaterialers repetitionsmuligheder.

Idéen om at vende udviklingen af e-læring på hovedet og tilrettelægge elæring som en samlet pakke efter undervisernes behov i forhold til aktuel undervisningspraksis har vist sig effektfuld i go online. Underviserne har selv været meget engageret i undervisningsudviklingen og i de fleste tilfælde selv stået for størstedelen af den både pædagogiske og teknologiske tilrettelæggelse. Dette har sparet E-læringsenheden for ressourcer og givet underviserne kompetencer til selv at udvikle nye e-læringsforløb og måske endda sprede det gode budskab. Det er min overbevisning, at universiteter er nødt til at løbende systematisere deres e-læringsservices samt at tage udgangspunkt i undervisernes aktuelle behov for at kunne rykke på dette felt. Endvidere forudsætter større, 'holistiske' services som fx go online en e-læringsafdeling eller projektgruppe, som både har, eller har direkte adgang til, de nødvendige pædagogiske, tekniske og administrative kompetencer. Det kan således være vanskeligt for afdelinger med et snævert fokus på fx it, pædagogik eller forskning at løfte denne type projekter uden supplerende støtte.

De overordnede anbefalinger, på baggrund af go online-projektet og dets idéer, er således:

- Tilbyd en 'komplet' e-læringspakke, der indeholder de nødvendige elæringsservices for at underviseren kan udvikle sin undervisning til elæring. Undervisere skal have let adgang til support og ikke besværes med administrative formaliteter og tekniske problemer, som kunne løses af projektgruppen. Go online-transformeringspakken, som er beskrevet i denne artikel, har vist sig nyttig og ville kunne tilpasses forskellige e-læringsudbud 
- Etablér en projektgruppe med både pædagogiske, tekniske og administrative kompetencer

- Tag udgangspunkt i undervisernes faglige ekspertise og e-læringspædagogiske behov. Underviseren er den faglige ekspert, og udviklingen af e-undervisningen bør tage udgangspunkt i vedkommendes viden om formidling af det aktuelle pensum til de studerende

- Tag udgangspunkt i et aktuelt kursus

- Sørg for at underviseren har opbakning fra egen institutleder til deltagelse i projektet

- Sørg for opbakning fra universitetsledelsen

- Inddrag evt. relevante, universitetspædagogiske enheder og forskningscentre

- Samarbejd evt. med centre for efteruddannelse og globalisering, da elæring bl.a. ville kunne muliggøre nye nationale og internationale uddannelsesudbud.

I takt med de seneste års vækst i antallet af e-læringsforløb er potentialerne ved e-læring blevet gransket. Adskillige udviklingsprojekter og forskning i feltet har demonstreret fordelene ved e-læring, men det er endnu meget uvist, hvorledes udviklingen skal organiseres for at være ressourcemæssig effektiv. Go online var et forsøg på at adressere denne udfordring, og erfaringerne fra pilotprojektet indikerer, at det, under de rette forhold, er og ville være muligt at udvikle e-læringskurser i forholdsvis stor målestok med relativt begrænsede midler. Vigtigst er det, at underviserne er med til at drive værket, og heldigvis, hvis man skal tro deres egne ord, havde de alle i høj grad lyst til at være underviser på et lignende kursus igen.

\section{Tak til}

Tak til Dorte Sidelmann Jørgensen for konstruktive kommentarer til artiklen samt involverede kolleger og undervisere for at gøre projektet muligt og bidrage til såvel planlægnings-, udviklings- og evalueringsarbejdet.

\section{Referencer}

Bonk, C. J. \& Graham, C. R. (2006). The Handbook of Blended Learning: Global Perspectives, Local Designs. San Francisco: Pfeiffer.

Cilia, J., Dupuis, M., Rothery. A \& Stenalt, M. S. (2008). EUNIS E-Learning Snapshots 2008. EUNIS 2008.

Collis, B. \& Moonen, J. (2001). Flexible Learning in a Digital World. Experiences and Expectations.. London: Kogan Page. 
Dalsgaard, C. \& Godsk, M. (2007). Transforming traditional lessons into problem-based blended learning: Experiences and challenges. In Open learning, Vol. 22, No. 1, pp. 29-42.

Dewey, J. (1916). Democracy and Education. New York: The Free Press.

Dewey, J. (1997). Experience and Education. New York: Touchstone.

Dirks, M. (1997). Developing an Appropriate Assessment Strategy: Research and Guidance for Practice. NAU/web.97 conference. Arizona.

Dokeos (2010). Dokeos | Open Source E-Learning. Set på http://www.dokeos.com/ d. 6. august 2010.

Driscoll, M. (1998). Web-based Training. Using Technology to Design Adult Learning Experiences. San Francisco: Jossey-Bass Pfeiffer.

Dron, J. (2007). Control and Constraint in E-Learning: Choosing When to Choose. IGI Global.

Garrison, D. R. \& Anderson, T. (2003). E-learning in the 21st century: a framework for research and practice. London: RoutledgeFalmer.

Godsk, M. (2006). Power to the teachers! Empowering teachers to author web-based learning material with easy-to-use tools. In Proceedings of the 12th International Conference of European University Information Systems. University of Tartu \& EUNIS. Tartu, pp. 278-282. EUNIS 2006.

Hayes, S., Godsk, M. \& Andersen, M.V. (2009). Inspiring Lecturers: Sharing E-Learning Practice through European Case Studies. In EUNIS 2009. IT: Key of the European Space of Knowledge. EUNIS 2009.

Heilesen, S., Jónsson, G. \& Randrup, B. (2007). IKT-kompetenceudvikling inden for undervisning og formidling på RUC. Rapport om hvordan elæring gribes an på danske og svenske universiteter samt om hvordan Roskilde Universitetscenter vil kunne etablere en kompetenceenhed. Roskilde Universitetscenter. Set på http://rudar.ruc.dk/bitstream/1800/2691/1/IKT kompetenceudviklin g_07.pdf d. 1. marts 2010 .

Laurillard, D. (2000). Rethinking University Teaching. London: RoutledgeFalmer.

Laurillard, D. (2002). Rethinking University Teaching. 2nd Edition. London: RoutledgeFalmer.

Lave, J. \& Wenger, E. (1991). Situated learning: Legitimate peripheral participation. Cambridge: Cambridge University Press. 
Mason, R. (1998). Models of Online Courses. In ALN Magazine. Vol. 2, issue 2. Sloan Consortium.

Paulsen, M. F. (2003). Online Education. Learning Management Systems. Bekkestua: NKI Forlaget.

Salmon, G. (2002). E-tivities. The key to Active Online Learning. London: Kogan Page.

Salmon, G. (2003). E-moderating. The key to teaching \& learning online. 2nd edition. London: RoutledgeFalmer.

Ubachs, G. (2009). Quality Assessment for E-learning a Benchmarking Approach. EADTU. Heerlen.

Videnskabsministeriet (2007). National strategi for IKT-støttet læring. Indsats for at fremme anvendelsen af IKT-støttet læring. Set på http://www.itst.dk/filer/Publikationer/National strategi for IKTstoett et laering/index.htm d. 2. august 2010. 